\title{
Fetching Poems from Elsewhere: Ciaran Carson's Translations of French Poetry
}

\author{
MIRIAM MCILFATRICK-KSENOFONTOV
}

\begin{abstract}
Ciaran Carson is a renowned Northern Irish poet with a distinguished record of translating poetry from Irish, Italian and French. This article focuses on his translation practice as evidenced in his three volumes of French poetry in translation: sonnets by Baudelaire, Mallarmé and Rimbaud; prose poems by Rimbaud; and poems by Jean Follain. Guided by the music, the matter, and the linguistic and ontological going-beyond of the originals, Carson variously 'adapts' prose poems to a rhyming alexandrine format, makes explicit use of derivation, shifts spatio-temporal perspective, and 'doubles' his French translations with English originals. Carson's approach of 'fetching' poems from 'elsewhere' is assessed in the light of Meschonnic's poetics of translation, which would define the overarching objective as producing new poems in English which do in English what the originals do in French. The analysis of Carson's new poems is also informed by conceptualizations of creativity and originality arising from research in cognitive science, literary studies and critical theory. Carson's practice of working under constraints suggested by the original poems and exploiting possibilities offered by and between the two languages leads to an expressive plurality that unsettles notions of source and target language. His translation artefacts and commentaries are examined for the light they shed on originality and derivation; writing and translating; the subjectivity of the translator; and the relationship between original poem and new poem.
\end{abstract}

Keywords: Ciaran Carson; translations of French poetry; poetics of translation; translator subjectivity; original; derivation

As elsewhere is

wherever we

are not there

are as many

elsewheres

as ourselves

$\cdots$

Ciaran Carson (2010: 104) 
Ciaran Carson is a Northern Irish poet whose creative output spans poetry, prose and translation. In forty years of literary activity, he has revealed himself to be a writer who blurs boundaries - in his experimentation with language, form and genre; in drawing on an eclectic range of literary, musical, historical and mythological sources; and in his exploration of the universal through the local, the foreign through the familiar. Carson has come to be known as a shapeshifting author, recognised precisely for his capacity for innovation and reinvention. He moves with apparent ease from narrative poems composed of sinuous long-lined rhyming couplets that echo Irish ballad metre and spill over the right-hand margin of the page to austere poems composed of extremely short lines - often only one or two words - that hinge on elision and disconnection. At times he offers a kaleidoscopic representation of his native Belfast - by turns harrowing and darkly humorous, at others he roves through revolutionary Ireland and France, war-time and cold-war Europe as far afield as imperial Japan, and on occasions he flits through a surreal no-man's-land or dreamlike neverland populated by characters from stories, history and myth. Also an accomplished musician, Carson skilfully exploits sound and rhythm, as well as incorporating into his poetry snatches of song and slang, slogans and jingles, anecdote and jargon, and multiple voices. While Carson's poetry defies easy categorisation, it might be said that he repeatedly takes the reader on a journey into otherness, rendering palpable the landscape en route.

In the introduction to his most recent volume of translation, From Elsewhere, a selection of poems by the French poet Jean Follain, Carson refers to what he was doing as a translator in terms of a journey and a quest: "fetching the poems from another language, from the elsewhere of [Follain's] territory" (2014: 14). This seems to resonate with Meschonnic's poetics of translation, which advocates that whatever the languages concerned, there is only one source, which is what a text does; there is only one target, to do in another language what that text does (1999: 23). In the case of poetry, this means making a new poem that is also an "other" poem, for it must continue to inhabit the space of literature but reach an audience in a different linguistic and cultural space. In elaborating on the word "fetch", Carson articulates what might be construed as his poetics of translation - for this collection at least:

[...] the definitions in the lengthy entry in the Oxford English Dictionary seem relevant to what I thought I might be doing. A fetch is an act of fetching, bringing from a distance, or reaching after: it is something brought from elsewhere, an act of translation in other words. To fetch is to draw or 'borrow' from a source. It is to derive etymologically. It is to go in quest of. In sailing, it is an act of tacking, and also to get into the wake of a vessel, as I fetched myself 
into the wake of Follain, and hence fetched my course, like a sailor who after a long fetch at sea comes home with a farfetched tale. A fetch is the apparition, double, or wraith of a living person. A shadowy counterpart, as my poems might be to those of Follain. (Carson 2014: 14)

The reference to "my poems" somewhat blurs the distinction between translating and writing. So too do the contents of the volume, for it is composed of translations of Follain's poems faced by Carson's response poems, which he describes as “'original' poems inspired by those translations: spins or takes on them in other words. Translations of the translations as it were" (ibid. 13) - no French originals appear in the volume. Carson's quotation marks around "original" suggest that he questions - or invites the reader to question - the appropriacy or the meaning of the term. What is clear, though, is his understanding that all the poems in the volume derive - flow - from his reading and thinking through Follain's poems. Apparently, translating f/From e/Elsewhere engaged Carson in a process of both linguistic and ontological going-beyond. ${ }^{1}$

In the first full-length study of the full range of Carson's oeuvre (poetry, prose and translation), Ciaran Carson: Space, Place, Writing, Neal Alexander notes the prominence of translation as "a longstanding and recurrent component of Ciaran Carson's work, not only as practice, process and artefact [...] but also as a theme or trope that relates to the multifarious effects of language itself" (Alexander 2010: 175). Consequently, he is surprised to find that in Carson's Collected Poems (2008), spanning more than thirty years of his poetic evolution in over 500 pages, "an artificial distinction seems to be drawn between his original poetry and his books of translation" (ibid. 1). The collection does not include any of Carson's versions of poems by the Romanian poet Stefan Agustin Doinas, which form the central section of Opera Et Cetera (1996), nor his versions of sonnets by Baudelaire, Mallarmé and Rimbaud, which constitute The Alexandrine Plan (1998). For Alexander this represents a missed opportunity to convey "the full extent of Carson's versatility and volatility as a writer" (ibid.); implicit in this comment is a view of translating and writing as part and parcel of Carson's creative evolution. Since then, Carson has continued to write and translate in abundance, producing two collections of poetry in English, two further volumes of poetry translated from French, and two novels in the space of six years.

1 I have elsewhere elaborated on this notion of the poet's desire and struggle to make known some partially perceived truth which neither she nor the language at her disposal is able to fully grasp - in the sense of understand and articulate, suggesting that this is both part of and the paradox of the creative process (see McIlfatrick-Ksenofontov 2013). 
McILFATRICK-KSENOFONTOV

So far most critical attention to Carson's translations of poetry has focused on how they relate to his own poetry rather than how they relate to the foreignlanguage originals. For example, the 17-syllable Japanese haiku that first appeared in The Irish For No (1987) is viewed as an influence on his innovative long line in the same volume. Likewise, his translation strategy for the haiku in Belfast Confetti (1989) is described as a type of "rewriting" that is part of his "method" of composing poems - for the translated haiku are "appropriated and recontextualized and made an integral part" of the collection (some inserted as lines in his long-line narrative poems; ten alternate with ten of his narrative poems, functioning as structuring epigraphs) (Malmqvist 2013: 11, 134). Similarly, the inclusion of translations of passages from Ovid's Metamorphoses and poems by Rimbaud, Baudelaire and Seán Ó Ríordáin in First Language (1993) is attributed to Carson's fascination with language as a medium of representation and his linguistic experimentalism in the collection as a whole. Furthermore, Carson's bilingualism (Irish and English) is judged to have attuned his ear and primed his imagination to find a creative mode of expression in exploring the space between languages. "Eesti" ${ }^{2}$, the opening poem of Opera Et Cetera, suggests as much: the sound of church bells in the streets of Tallinn and the name of the country chime in the mind of the adult to evoke a childhood memory of attending mass with his father in Belfast, leading him to produce lines in which sound and sentiment echo and overlap: "This red-letter day would not be written, had I not wandered through the land of Eesti./ I asked my father how he thought it went. He said to me in Irish, Listen: Éist $^{3}$ " (1996: 7-8). Even The Alexandrine Plan, which consists solely of his translations of French sonnets, is generally linked to The Twelfth of Never, which consists of Carson's own sonnets in rhymed alexandrines and appeared in the same year (suggesting simultaneous composition).

In what follows, I will focus on Carson's three volumes of French poetry in translation: The Alexandrine Plan (1998), sonnets by Baudelaire, Mallarmé and Rimbaud; In the Light of (2012), prose poems by Rimbaud; and From Elsewhere (2014), poems by Jean Follain. The original poems are all products of the same linguistic and cultural sphere, and the new poems are assessed in the light of Meschonnic's poetics of translation, thus assuming an overarching objective of producing new poems in English which do in English what the originals do in French. Carson's practice of translation is examined for what light it sheds on originality and derivation; writing and translating; the subjectivity of the translator; and the relationship between original and new.

\footnotetext{
2 "Eesti" ['e'sti] is the Estonian for "Estonia".

3 "Éist" ['e: $\mathfrak{t}$ ] is the Irish for "listen".
} 
Fetching Poems from Elsewhere

We say that an author is original, when we cannot trace the hidden transformation that others underwent in his mind. What a man does either repeats or refutes what someone else has done - repeats it in other tones, refines or amplifies or simplifies it.

Paul Valéry's “Letter about Mallarmé” (1972: 241)

Carson has not been selected with a view to suggesting that as an awardwinning poet his translations are in some sense exemplary or that he is entitled to a more personal or adaptive response. Rather, his translations and commentaries over two-and-a-half decades suggest that for him translation is an ongoing exploration of reader's perception and writer's expression, and of the limits and potential of language. These are questions that concern all practicing translators. The fact that translation is part of the continuum of Carson's life as a writer invites reflection on the distinction between translating and writing, bearing in mind two assumptions. First, since translation is uniquely a form of reading that is realised as writing, all translators are cast in the role of writers. As such, they work with language that is no more at their disposal than it is for the writer of the original. Second, irrespective of who the translator is his translation practice inevitably reveals his notion of language and literature - what he judges possible or impossible to do with language and what constitutes a poem (Meschonnic 1999: 80, 243). Hence, Carson's translations of poetry reveal his idea of what poetry is, and his own poetry and his translated poetry bear comparison.

A cognitive approach to translating poetry is concerned precisely with how the translator constructs a reading of the original and how that reading is carried over into the translation while preserving the essentially interactive nature of the poem and the effects it produces that make us attend to it as a poem (BoaseBeier 2006a: 55-56; 2006b: 71-145; Lange, McIlfatrick-Ksenofontov 2015). As such, it foregrounds the subjectivity and the agency of the translator. So too do theorists and practitioners who speak of (or hope for) a "creative turn" in translation studies (see Perteghella, Loffredo 2006; Bassnett, Bush 2006). This is opening up new perspectives on the inter-related notions of creativity and originality - usually in association with postmodern theory and its blurring of boundaries and subversion of hierarchical values (such as original and copy, and, by extension, writing and translating). So far, however, less has been done to problematize the terms than to demonstrate that literary translation merits rethinking and recognition as creative writing - largely through examples of practice and supporting conceptualizations grouped under "the unifying theme of creativity" (Loffredo, Perteghella 2006: 11). While there is no consensus on how to define creativity, recent research in cognitive science, literary and 
McILFATRICK-KSENOFONTOV

cultural studies, and critical theory offers sufficient pointers for it to be a useful and usable part of the translation studies lexicon.

From a cognitive science perspective, creativity has been defined as the ability to come up with "ideas or artefacts that are new, surprising and valuable" (Boden 2004: 1). Rather than a special or single capacity, it is an aspect of human intelligence "grounded in everyday abilities such as conceptual thinking, perception, memory, and reflective self-criticism” (ibid.). Boden specifies that there are three main types of creativity - combinational, exploratory, and transformational, and that novelty may be understood with reference to the individual or all of human history. She also notes that most arguments over creativity are rooted in disagreement over the question of value, largely because values change over time and across groups and cultures. (ibid. 2-10). In the light of critical theory and cultural history, Rob Pope formulates his view of creativity in terms of what is original and fitting: "'original' in the sense both of drawing on ancient origins and of originating something in its own right; either way, the overall aim or end is a 'fitting' - an active exploration of the changing proportions, measure, ratios - between older modes of understanding and newer ones" (Pope 2004: 59-60). Fitting is further elaborated as "filling an appropriate space" and "fulfilling an appropriate role or function", thus embracing the notion of approval (ibid. 57-60). Returning to the field of literary production and reception, Robert Macfarlane demystifies both notions in an eloquent articulation that takes its cue from Paul Valéry (as cited above):

Originality is not an indwelling quality of writerly production, but instead a function of readerly perception, or more precisely readerly ignorance (the failure to discern a writer's sources). Writing is a continual process of tuning out ('refutes'), turning up ('amplifies'), or fine-tuning ('refines') what someone else has done, and all writers thus either inhabit or inhibit the language of 'others'. Creation is always, and appropriately anagrammatically, reaction." (Macfarlane 2007: 5).

Macfarlane also emphasizes that originality (like plagiarism) does not exist in a positive or objective sense and is not identifiable by recognisable textual features - as, say, a sonnet or a haiku is. It is a pragmatic, rather than textual, phenomenon and a judgement "determined by a wide variety of extra-textual criteria that constitute the aesthetic, institutional, and cultural contexts of production and reception of the work" (ibid. 13-14).

In sum, an understanding of creativity depends on an overlap of distinctions and connections. The newness at the heart of all definitions is also old, for it is always in relation, response or reaction to something else or other. 
Fetching Poems from Elsewhere

the artist expresses what he perceives, he perceives what he expresses

Herbert Read (1998 [1968]: 12)

\section{The Translator's Plan}

Carson's name and the title The Alexandrine Plan feature on the cover of this first full-length collection of poetry in translation. Only inside do we see the subtitle "Versions of Sonnets by Baudelaire, Mallarmé and Rimbaud", followed by originals and translations on facing pages. In the Author's Note to his second volume of translated poetry, In the Light of, Carson offers a retrospective comment: "My concern in that book was not so much to give a 'literal' meaning of what the poems might be saying, as to reproduce the original metre in English, and see what interpretations might emerge from those constraints, both of rhyme and the twelve syllables of the classical French alexandrine" (Carson 2013: 12). This speaks of an exploratory and experimental approach from the outset, and a regard for the music as much as the matter of the poems. Carson imposes formal constraints knowing - as a poet - that this will allow him to engage with language in a way that affords new possibilities and new vistas:

The poet often doesn't know what he has in mind; he follows the language, and sees where it might lead him, which is usually a very different place from what he thought at the outset. If you know exactly what you are going to say in a poem, that poem will be a failure. Besides, there is no interest or fun in saying what you already know. Poems are devices for learning what you never knew until you wrote the poem. They take you elsewhere. (Carson 2012)

Constraints - if neither too many nor too restrictive - are simultaneously a means of controlling the myriad possibilities that thought and language offer and of stimulating creativity, like play in a rule-bound game.

As a translator, Carson is "following" two languages - one in the light of the other, and this is often apparent in the translations. For example, feminine nouns personified in the original are prefixed by a feminine title in English: "La Mort" - "Mistress Death", "Ô Beauté" - "Mistress Beauty", "L’Angoisse" - "Madame L'Angoisse". Or the French is allowed to twist the English into a new shape and direction, as in the poem "La Maline". The title is a deviant form in French, the feminine of malin is maligne; it is a small step - orthographically and acoustically - from there to "Miss Malinger" (purely 
McILFATRICK-KSENOFONTOV

a verb form in English, "malinger" is derived from French and its current meaning of pretending or exaggerating illness fits the discourse of the poem perfectly). Thus "La Maline" and "Miss Malinger" share origins and agendas; the latter sees herself as "a walking centrefold”, appears "décolletée" (in a shift from "fichu moitié défait" to more risqué English), and flirtatiously plays up a hint of a cold: "Feel here, dis cheek's caught cold". Throughout the volume there is a marked use of words of French derivation and French loanwords, e.g. "voyeur and poseur", "entourage" and "camouflage", "communiqué" and "negligée". And occasionally the French is turned back on itself, e.g. "Ô vers! noirs compagnons sans oreille et sans yeux" becomes "O worms - my noir compatriots, sans eyes, sans ears". The French is never far from eye or ear visible on the left-hand page and regularly informing or inhabiting the English.

Equally visible is a recurrent use of capitalization: soldiers fall in "the Zone of Furrows" ("dans tous les vieux sillons"), a splenetic type wallows in "the Pit of Tedium" ("gouffre de l'Ennui"), and Man stumbles through "the Forest of Belief" ("des forêts de symboles"). This is mostly in response to lines that employ the vocative "Ô" for a dramatic or reverential tone. Carson's capitalization sets the words apart and is reminiscent of John Bunyan's Christian allegory, The Pilgrim's Progress (1678), thus replicating both form and effect.

As Carson thinks in and out of the two languages, the linguistic choices he makes consistently support the emerging discourse of each new poem and the tenor of the collection as a whole. Much is made of his ability to produce striking rhymes, and many of his end rhymes do audibly animate the English versions. For example, in "The Green Bar", "she filled my beer mug" is echoed in a satisfied "I guzzled it all into me. Glug. Glug. Glug. Glug", while in Rimbaud's "Au Cabaret-Vert" a tankard is filled but no drinking seen or heard. In "Recalling the Belgian Friends", the buildings in Carson's "unpremeditated Bruges" of "stilled canals of subterfuge" are "mildewed" in their "decrepitude", audibly marking it as a place of unplumbed depths and growing decline. By contrast, Mallarmé's Bruges is evoked in terms of what it is not ("le jamais banal / Bruges") and what is past ("défunt canal"), and nothing stirs ("émeuve") its widowed stone ("pierre veuve"). In creating end rhymes that highlight palpable detail, Carson gives the new poems a different pitch or intensity than the more subdued French.

Embedded in Carson's poetics of fetching poems from elsewhere is the notion of the return and bringing something back - but back to where? It is tempting to look for evidence of shifts that would locate the new poems in an identifiable time and place, but Carson offers no such fixity. Certainly, his version of the opening sonnet, "Au Cabaret-Vert", takes the reader to "the 
old Green Bar" in "Kingstown" (a temporary nineteenth-century name for an Irish sea town south of Dublin) with its "shamrock / table" ("table verte") and "tacky 50s décor". There is a hint of that global phenomenon that is the Irish pub in this otherwise formally perfectly rendered classical alexandrine sonnet. However, this is not allowed to develop into a stereotypical Irish veneer. Rather, the poem evokes a conceivable modern-day pub encounter in the not very politically correct voice of a footsore walker at the end of the day, as he eyes with equal relish the food and the waitress: in her "tit-enhancing frock", she "wiggled up to me, her eyes galore // with hints of smoochy kisses" ("la fille aux tétons énormes, aux yeux vifs, // - Celle-là, ce n'est pas un baiser qui l'épeure! - ”). In the collection as a whole, spatio-temporal shifts are rendered through a diversity of contemporary voices, registers, and cultural references. "Ma Bohème" becomes "On the Road”, alluding to Jack Kerouac's 1957 road-trip-inspired novel and fitting for a poem by the restless, runaway Rimbaud. This is echoed and extended in the new version of Baudelaire's "Bohémiens en voyage", where the "Travellers" of the title "hit the road" and are "like Jack Kerouacs", potentially putting the reader in mind of the Irish itinerant ethnic group (Irish Travellers) and the song "Hit the Road, Jack" (made famous by Ray Charles in 1961). Times and places are not always those of the original nor are they fixed, yet a sense of continuity pervades the collection.

The weaving of contemporarizing references into the new poems is sufficiently supple to universalize as well as to specify. In two of Rimbaud's poems exposing the absurdity of war ("L'Éclatante Victoire de Sarrebrück" and "Le Mal"), infantrymen ("les bons Pioupious") emerge as modern-day "squaddies"; credulous soldier types rendered by French placeholder names ("Pitou"; "Dumanet" and "Boquillon") are forgettably familiar as "one guy", "another half-wit" and "Joe Bloggs"; and grieving, black-bonneted mothers are lumped together as "Mrs Nobody". More poignantly, the "rouges canons" of the Franco-Prussian War stand out as "red poppy field guns" - channeling the sentiment of the original through a war reference more familiar to the contemporary reader.

Carson takes full advantage of the fact that words do not have the reality that they express, that they are "nothingness in action" (Blanchot 1982 [1955]: 39), and that between word and referent stands the mind of the reader. This allows for the creation of versions that offer perspectives on the French poems that were not possible at the time of their publication. Clive Scott views this as a kind of "fictionalization", in the sense that we cannot tell the truth about a text in translation, but we may perhaps tell the truth about a text that does not yet exist, that might exist if we were to place it in a space that the source 
text has yet to occupy; in other words, translation may "go out to meet its fictionality" (Scott 2006: 33-34). This is what Carson does when he puts Rimbaud's and Baudelaire's travellers "on the road". Similarly, in rendering Baudelaire's "La Géante" as "The Maid of Brobdingnag", Carson locates her origins in the fictional land of giants (Brobdingnag) of Jonathan Swift's Gulliver's Travels (1726). This opens a space that accommodates the "I" of the new poem as a would-be Gulliver; he continues to wish - like the "je" of the original - that he could have explored the body of a giant girl he imagines once existed and that he conceives of as a physical terrain. Carson's giant girl is more earthily mapped than Baudelaire's - "her Mount Parnassus" and "snowy Alpine paps" overshadow "ses magnifiques formes" and "ses seins". As a result, the reader is afforded a Gulliver-inspired make-believe that is grounded in a blurring of real world and real fiction. Carson creates a new poem that is also an original poem, for it draws on and departs from what preceded it and originates new readings.

Viewed in this light, Carson both fetches poems from elsewhere and places the new versions elsewhere, which seems to blur the poet-translator distinction. The final sonnet of the collection, his version of Baudelaire's "La Beauté" contains the line: "And nothing will disturb my alexandrine plan" ("Je hais le movement qui déplace les lignes" - literally, I hate the movement that displaces the lines). It is hard not to hear Carson's voice here, for it expresses his declared intention to see what would emerge from the constraints of the alexandrine. And still there is Baudelaire's voice, for this allegory of beauty is also an ars poetica; and then again there is the voice of the poem, of the very French alexandrine that inspires, dictates and delivers this collection.

Carson's intervention is echoed again in a similar conflation or confusion of voices in "Le Sonneur" - literally, the bell-ringer, now "The Sonneteer". The title seems to have been prompted by what the "lonely campanologist" exclaims, and what both poet and translator could equally well claim: "I am that man. Alas! Most nights I dangle on / An anxious tangled cable" and "one of these fine days ... I'll hang myself $[\ldots]$ with the self-same rope". The "rope" can be construed as the same alexandrine line that constrains the French poet(s) and this translator. Whichever voice(s) we choose to hear, it is certainly Carson who has worded his plan into these lines and through these versions. And he is the sonneteer who produced a further 77 alexandrine sonnets in The Twelfth of Never (as mentioned above) - same year, same plan, same rope. 
Fetching Poems from Elsewhere

\section{After Another Author}

Carson's second volume of translated poetry, In The Light Of, is subtitled "after Illuminations by Arthur Rimbaud". ${ }^{4}$ A reader familiar with Rimbaud's work might expect versions of prose poems from the collection Illuminations but probably not the rhyming alexandrine couplets that Carson offers. In his "Author's Note", Carson explains that early attempts at translating Rimbaud's prose poems produced "inert, flabby, prosaic" results; his dissatisfaction lay in not being able to "arrive at any form of words that did justice to $m y$ understanding of what they might imply or mean, or to my sense of their music" (Carson 2013: 12; italics added). Over a decade later and after an "illumination of [his] own", he opted to "adapt" them to an alexandrine format (ib.). This rapidly led to 22 verse poems, distributed equally in Act One and Act Two, with three prose versions framing them - one before, between and after the Acts (French originals are not included). Carson's determination to do justice to his perception of the poems along with his very deliberate composition of the book go some way to explaining why he adds an author's note rather than a translator's note. This is "not the book that is Rimbaud's Illuminations, but another, taken from that book" (ibid. 13). As well as an act of fetching, translation had become an act of making other.

Working within constraints of rhyme and metre allowed Carson to detect parts of Rimbaud's poems that had "a prosody of their own, scanned, rhymed, alliterated" and to deliver these "incipient sonnets" into English, in an act of "restoration, or renovation" (ibid.). In so doing, he re-enacts Rimbaud's redefining of himself as a poet, in so far as Rimbaud's experiment with a radically new poetic structure is replicated in a form that is both uncommon in contemporary English-language poetry and a surprise for the reader who expects prose poems. Carson is also guided by the effects of Rimbaud's unconventional linguistic choices and his diverse registers and voices, as well as by his use of words for their evocative quality. Sometimes he offers same for same, e.g. replicating many of the foreign or distorted words: "Tall tasses steamed" for "les 'mazagrans's fumèrent"; mysterious "Timberwomen" for "bûcheronnes". Elsewhere he lets Rimbaud and the French language twist his words ("une porte claqua" becomes "a door clacked"), inhabit his lines ("Voilà! Veil after veil I lifted" for "Alors je levai un à un les voiles") or inspire

4 In the original 2012 Gallery Press edition; the 2013 US edition reads "after illuminations by arthur rimbaud".

5 "Mazagran" is an iced coffee beverage originating from Algeria 
a new take on a poem ("Antic" replaces "Antique" in a tribute to the mythological Pan). However, no single strategy is used slavishly throughout. Thus, for example, whenever Rimbaud's elliptical and elaborate syntax resists his alexandrine plan, he allows the new lines to find their own length simultaneously breaking his own rule and emulating the rule-breaking Rimbaud.

Carson reintroduces the question of the poet-translator distinction in his response to one of Rimbaud's riddling last lines. "J'ai seul la clef de cette parade sauvage" is equally ambiguous but also dialogic as "And who's behind this wild curtain raiser? I, my friend". It rebounds tellingly on Rimbaud's own formulation "Je est un autre", for in making poems that are innovative as Rimbaud's are, Carson has engaged in the linguistic and ontological goingbeyond that is the lot of the poet.

\section{From One Elsewhere to Another}

In From Elsewhere, the reader, having no access to the original French, cannot see how Carson might have arrived at his translations nor whether - in his "originals" - he is reacting to his own or to Follain's words. Only the French titles are given, separated from the English titles by a colon. The translated titles reflect straightforward choices; the "original" titles, however, are at more or less of a remove, e.g. "Le globe: The Globe" gives rise to "The Geography Lesson" but "L'Oeuf: The Egg" to "Rifle".

A comparison of French originals, Carson's translations and Carson's "originals" reveals a sustained formal and stylistic similarity characterised by syntactic elasticity (most poems are a single sentence, all are laid out in unor under-punctuated run-on lines); elision of the first person; anonymous or archetypal characters; and a spare, synoptic view that lacks comment or exposition. Words seem to touch things directly, as poems dart swiftly from one image to the next. Carson adds a note regarding Follain's admiration for and emulation of the transparency of John Clare's poetry - that "near absence of metaphor in a poetry where all things are equal in the field of vision" (Carson 2014: 185).

6 "Antic", from the same Latin "antiquus" as "antique", originally referred to strange or fantastic representations on ancient murals unearthed around Rome, but later extended to any bizarre or grotesque thing or behaviour. 
A comparison of the translations and the "translations of the translations" reveals a similarity of "mind style", understood here as the cognitive state that a reader constructs as lying behind a poem, as expressed in the poem's voice and demanding maximum reader engagement in processing the gaps, signals, ambiguities and complexities of the poem. This is a state that is influenced by ideology, takes a particular attitude and embodies a particular feeling. (BoaseBeier 2006a: 55; 2006b: 75-82). Follain's originals explore and give voice to a melancholy sense of loss or imminent disruption, and the ephemeral nature of all that we see and hear in the present. As Carson translates Follain, exploring how this is created in and by the text, he is in effect learning what the poet does and how. These become his new constraints, the rules of the game for making a new poem in the same landscape. For example:

Pensées d'octobre: October Thoughts

How good it is

to drink this fine wine

all by oneself

when evening illuminates the coppery hills

no hunter any longer sets his sights

on the lowland game

our friends' sisters

look lovelier than ever

regardless of the threat of war

an insect stops

then starts again.

Throwback

Children throwing stones

and bottles over the brick wall

topped with broken bottles

ruby amber green

need not know who

drank the wine

all those years ago

nor what lies on the other side

except that it throws back. 
In "Pensées d'octobre: October Thoughts", a moment of mellow stillness is savoured, a brief hiatus between two forms of violence (hunting and war), its fragility redoubled by the oblivious insect. In "Throwback", urban children are glimpsed at their violent games, ignorant of things past and unseen, simply caught up in the familiar gestures of the moment. We know that Follain writes out of war-time France and Carson out of Ulster with its $t$ /Troubled history, but characters and scenes are momentarily abstracted from the world of history. The new poem both performs the throwback of its title - in the sense of a reversion to an earlier time or type - and expresses it as the original does. Reading the poems of From Elsewhere side by side allows one to wonder whether Carson's poems follow Follain's or Follain's foreshadow Carson's, for they both reach into the same imaginative hinterland. As such, Carson's "shadowy counterparts" shed new light on his questioning of the word "original”.

\section{Fetching Poems}

Ciaran Carson is a poet who translates and a translator who makes poems, and the motivation is always the same - to learn something new. His poetic practice of following the language to see where it leads is his way of exploring the possibilities and limitations of his language - how it affects, implies, and offers ways of seeing and saying. To translate a poem as a poem, then, is to replicate this process, for Carson's translation commentaries and artefacts suggest that he sees no hierarchical distinction between writing and translating. The desire to translate a poem is already participation in it - a recognition of some mind-altering value in the other poet's words. Replicating the process of knowing from the inside and learning something new now means working in and out of two languages.

Working under constraints suggested by original poems and possibilities offered by and between the two languages, Carson makes linguistic choices that allow for an expressive plurality that - to a greater or lesser extent unsettles notions of source and target language. A poem is not found in one language and placed into another, nor is the new poem seen in advance - it emerges in the process of the coming and going between the two languages. Ultimately and in the light of theories of creativity, the perception of whether or not the new poems are "fetching" - in the sense of attractively fitting - lies with the new readers. 
Fetching Poems from Elsewhere

\author{
Miriam McIlfatrick-Ksenofontov \\ miriamk@tlu.ee \\ Tallinna Ülikool \\ Humanitaarteaduste Instituut \\ Narva mnt. 29 \\ 10120 Tallinn \\ EESTI / ESTONIA
}

\title{
References
}

Alexander, N. 2010. Ciaran Carson: Space, Place, Writing. Liverpool: Liverpool University Press.

Bassnett, S. 2006. Writing and Translating. - S. Bassnett, P. Bush, eds. The Translator as Writer. London and New York: Continuum, 2006, 173-183.

Blanchot, M. 1982 [1955]. The Space of Literature. [A. Smock, transl.] Lincoln: University of Nebraska Press.

Boase-Beier, J. 2006a. Loosening the grip of the text: theory as an aid to creativity. M. Perteghella, E. Loffredo, eds. Translation and Creativity: Perspectives on Creative Writing and Translation. London, New York: Continuum, 47-56.

Boase-Beier, J. 2006b. Stylistic Approaches to Translation. Manchester, UK, Kinderhook, USA: St. Jerome Publishing.

Boden, M. 2004. The Creative Mind: Myths and Mechanisms London: Routledge.

Carson C. 1996. Opera Et Cetera. Newcastle upon Tyne: Bloodaxe Books.

Carson, C. 1998. The Alexandrine Plan. Loughcrew: The Gallery Press.

Carson, C. 2010. Until Before After. Loughcrew: The Gallery Press.

Carson, C. 2012. Interview: Ciaran Carson on translating Rimbaud. Interview by O’Malley JP. - The Spectator, 02 Nov. 2012: n.pag. http://blogs.spectator. co.uk/2012/11/interview-ciaran-carson-on-translating-rimbaud/ (16.04.2015).

Carson, C. 2013 [2012]. In the Light Of. Winston-Salem, NC: Wake Forest University Press.

Carson, C. 2014. From Elsewhere. Loughcrew: The Gallery Press.

Lange, A., McIlfatrick-Ksenofontov, M. 2015. Tõlkepoeetikast teksti ja keele taustal. -Methis. Studia humaniora Estonica, 16, 156-174.

Loffredo, E., Perteghella, M. 2006. Introduction. - M. Perteghella, E. Loffredo, eds. Translation and Creativity: Perspectives on Creative Writing and Translation Studies, London and New York: Continuum, 1-16.

Macfarlane, R. 2007. Original Copy: Plagiarism and Originality in Nineteenth-Century Literature. Oxford: Oxford University Press.

Malmqvist, J. 2013. Belfast Textiles: On Ciaran Carson's Poetics. Linköping: Linköping University Electronic Press.

McIlfatrick-Ksenofontov, M. 2013. Where the Truth Lies in Translated Poetry: a Doris Kareva Poem in English. - Interlitteraria, 18(1), 168-183.

Meschonnic, H. 1999. Poétique du traduire. Paris: Verdier. 
McILFATRICK-KSENOFONTOV

Perteghella, M., Loffredo, E., eds. 2006. Translation and Creativity: Perspectives on Creative Writing and Translation Studies, London and New York: Continuum.

Pope, R. 2005. Creativity: Theory, History, Practice. London: Routledge.

Read, H. 1998 [1959]. A Concise History of Modern Painting. London: Thames and Hudson.

Scott, C. 2006. Translation and the spaces of reading. - M. Perteghella, E. Loffredo, eds. Translation and Creativity: Perspectives on Creative Writing and Translation Studies, London and New York: Continuum, 33-46.

Valéry, P. 1972. Leonardo, Poe, Mallarmé. [M. Cowley \& J. R. Lawler, transl.] London: Routledge \& Kegan Paul. 